\title{
Optimization of hydraulic fracturing treatment in tight sand reservoir of lower indus basin: an integrated approach
}

\author{
Faizan Ali $^{1} \cdot$ Muhammad Hassaan Chaudhry ${ }^{1} \cdot$ Muhammad Arqam Khan ${ }^{1}$ (D $\cdot$ Qazi Ismail Ahmed ${ }^{2}$
}

Received: 26 July 2021 / Accepted: 30 November 2021 / Published online: 29 December 2021

(c) The Author(s) 2021

\begin{abstract}
An approach for post-frac production profiling has been presented in this study by integrating a fracture model with a reservoir simulation model for a well drilled in tight sand reservoir of Lower Indus Basin in Pakistan. The presented integrated approach couples the output from the fracture growth model with a reservoir simulation model to effectively predict the behavior of a fractured reservoir. Optimization of hydraulic fracturing was done efficiently through the work presented in this study. The integrated model was used to perform various sensitivities. The production profiles obtained for each case were subsequently used to determine the most profitable case, using an economic model.
\end{abstract}

Keywords Hydraulic fracturing $\cdot$ Tight gas $\cdot$ Fracture growth model $\cdot$ Lower indus basin $\cdot$ Optimization · Integrated approach

$\begin{array}{ll}\text { Abbreviations } \\ \text { Bbl } & \text { Barrels } \\ \text { BOE } & \text { Barrels of oil equivalent, boe } \\ \text { BTU } & \text { British thermal unit } \\ \text { BSCF } & \text { Billion standard cu.ft. } \\ \text { CAPEX } & \text { Capital expenditures, \$ } \\ \text { Klbs } & \text { Kilo pounds } \\ \text { LGR } & \text { Local Grid Refinement } \\ \text { mD } & \text { Millidarcy } \\ \text { MMSCF/D } & \text { Million SCF/D } \\ \text { NPV } & \text { Net present value, \$M } \\ \text { PPG } & \text { Pounds per gallon } \\ \text { OPEX } & \text { Operational expenditures, } \$ \\ \text { SCF } & \text { Standard cu. ft. } \\ \text { STB } & \text { Stock tank barrel } \\ \text { TCF } & \text { Trillion cubic ft. } \\ \text { TD } & \text { Total depth }\end{array}$

Muhammad Arqam Khan

arqamkhan@ neduet.edu.pk

1 Department of Petroleum Engineering, NED University of Engineering \& Technology, Karachi, Pakistan

2 United Energy Pakistan Limited (UEPL), Karachi, Pakistan

\section{Introduction}

Pakistan has been blessed with tremendous amount of hydrocarbon resources including tight gas. As per different studies, the amount of tight gas resources in Pakistan are in the range of $24 \mathrm{TCF}$ to $40 \mathrm{TCF}$ (Alam 2011). Tight gas resources are present in various formations of Pakistan such as Sulaiman Fold belt, Middle Indus Basin, and Kirthar Fold belt, Potwar region, Lower Indus Basin, and Offshore areas. As conventional hydrocarbon resources of Pakistan are rapidly declining (Raza et al. 2019), it is highly imperative that the unconventional resources including tight gas are developed to reduce the ever-increasing demand and supply energy gap. The effective permeability of different tight gas formations in Pakistan ranges between 0.01 and $1 \mathrm{mD}$ (Alam 2011). Mahmud at el. reported permeabilities between 0.02 and $1.17 \mathrm{mD}$ and porosities between 8 and $15 \%$ in their study performed on samples acquired from Lower Nari Sandstones of Southern Indus Basin and Indus Offshore (Sheikh 2012). Development of tight gas resources will definitely play a major role in meeting energy need of Pakistan.

Tight reservoirs are usually developed using horizontal well and hydraulic fracturing techniques but have very low recoveries (Wang et al. 2018). Sustainability of production rates is the key challenge among the various other challenges in developing a tight reservoir (Dahraj et al. 2018). Following parameters are considered in designing a hydraulic fracture treatment: wellbore configuration, reservoir parameters,

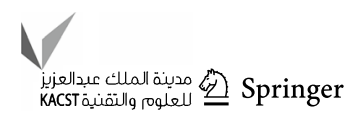


rock strength, reservoir stress distributions, porosity and permeability, injection rate and pump schedule and other critical operational parameters including size, number and location, phasing angle of perforations, fluid and proppant type (Salman 2015; Sharma et al. 2019; Kolawole et al. 2019).

Predicting the effect of a designed hydraulic fracturing job on reservoir performance is a major technological challenge for reservoir engineers (Cohen et al. 2012). Usually, production predictions for a designed hydraulic fracturing job are done through numerical methods (Ai et al. 2018; Suboyin et al. 2020). Different methods have been suggested in the literature. Huang et al. (2018) presented a numerical method to predict the production performance of a hydraulic fractured shale gas well under different scenarios. Guo et al. (2019) studied the effect of fracturing parameters on tight gas production using a prediction model. Jayakumar et al. (2013) used a synthetic model to describe the effects of various fracturing parameters on the production profile of a shale reservoir. David et al. (Waters and Weijermars 2021) predicted the production performance of shale gas wells using an analytical flow cell model. Urban et al. (2016) discussed a shale gas production model to forecast future production and recovery under the influence of various fracturing parameters. Computational efficiency is an important issue when production predictions are done through numerical methods and may lack necessary theoretical basis (Ai et al. 2018).

The study focuses on following deliverables:

1. To design and simulate hydraulic fracture treatments; understanding the quantities required for input, the processing that is being carried out, and the outputs that are obtained.

2. To integrate a fracture growth model into a sector reservoir model, in a bid to effectively model the behavior of a fractured reservoir.

3. To perform an economic analysis of fracture treatments to determine the best-case scenario from the results obtained from the integrated model.

Commercial hydraulic fracture simulator FRACPRO and reservoir simulator Eclipse have been utilized in this study to design and simulate a hydraulic fracture treatment.

\section{Methodology}

At the initial stage, a fracture growth model was developed using the data for the well (labeled as Well 01) drilled in the Lower Guru Formation of the Lower Indus Basin of Pakistan. The pay zone is a tight formation having permeability of $0.15 \mathrm{mD}$ and filled with dry gas. The porosity of the formation is $10 \%$, and the initial connate water saturation is
Table 1 Initial input parameters for Well 01 in the fracture growth model

\begin{tabular}{ll}
\hline Wellbore orientation & Vertical \\
\hline Pay zone & X394-X600 ft \\
Perforation interval & X394-X433 ft \\
Surface temperature & $84^{\circ} \mathrm{F}$ \\
Reservoir temperature & XX6 $6^{\circ}$ \\
Reservoir pressure & X066 psig \\
Drainage area & $1 \mathrm{sq} \cdot \mathrm{km}$ \\
Permeability & $0.15 \mathrm{mD}$ \\
Water saturation & $31 \%$ \\
Closure gradient & $0.90 \mathrm{psi} / \mathrm{ft}$ \\
Poisson's ratio & 0.25 \\
Shear Modulus (psi) & $3.14 \mathrm{E}+06$ \\
Young's Modulus (psi) & $5.5 \mathrm{E}+06$ \\
Bulk Modulus (psi) & $3.40 \mathrm{E}+06$ \\
Biot Coefficient & 0.58 \\
Closure pressure (Psi) & 3900 \\
\hline
\end{tabular}

$31 \%$. The net pay thickness of the pay zone is around $200 \mathrm{ft}$. The data used for this model are given in Table 1.

The process flow used in the development of this fracture growth model is described in Fig. 1.

After the development of fracture growth model, treatment designs and fracture geometry were defined for Well 01 . The next stage was the development of an integrated model which included coupling of fracture model and with reservoir simulation model. The process flow for the development of integrated model is given in Fig. 2.

To design an optimum hydraulic fracture treatment for the Well 01, following different scenarios were run for the integrated model, which are given in Table 2.

The cases were selected to observe the effects of following listed parameters on the net revenues of the project:

- Orientation of well

- Length of Lateral

- Number of fracture stages

- Fracture Spacing

These factors have a pivotal effect on field recovery and hence the profits, the reason being that a change in any of the above parameters in a simulation will be conducive to different costs being incurred in that scenario, at the same time yielding different volumes of hydrocarbons being produced and ultimately different profits.

Using the integrated approach, average and total rates for gas and water production were calculated for different fracturing approaches. Finally, economic modeling was performed for all the cases and the NPV (net present value) 


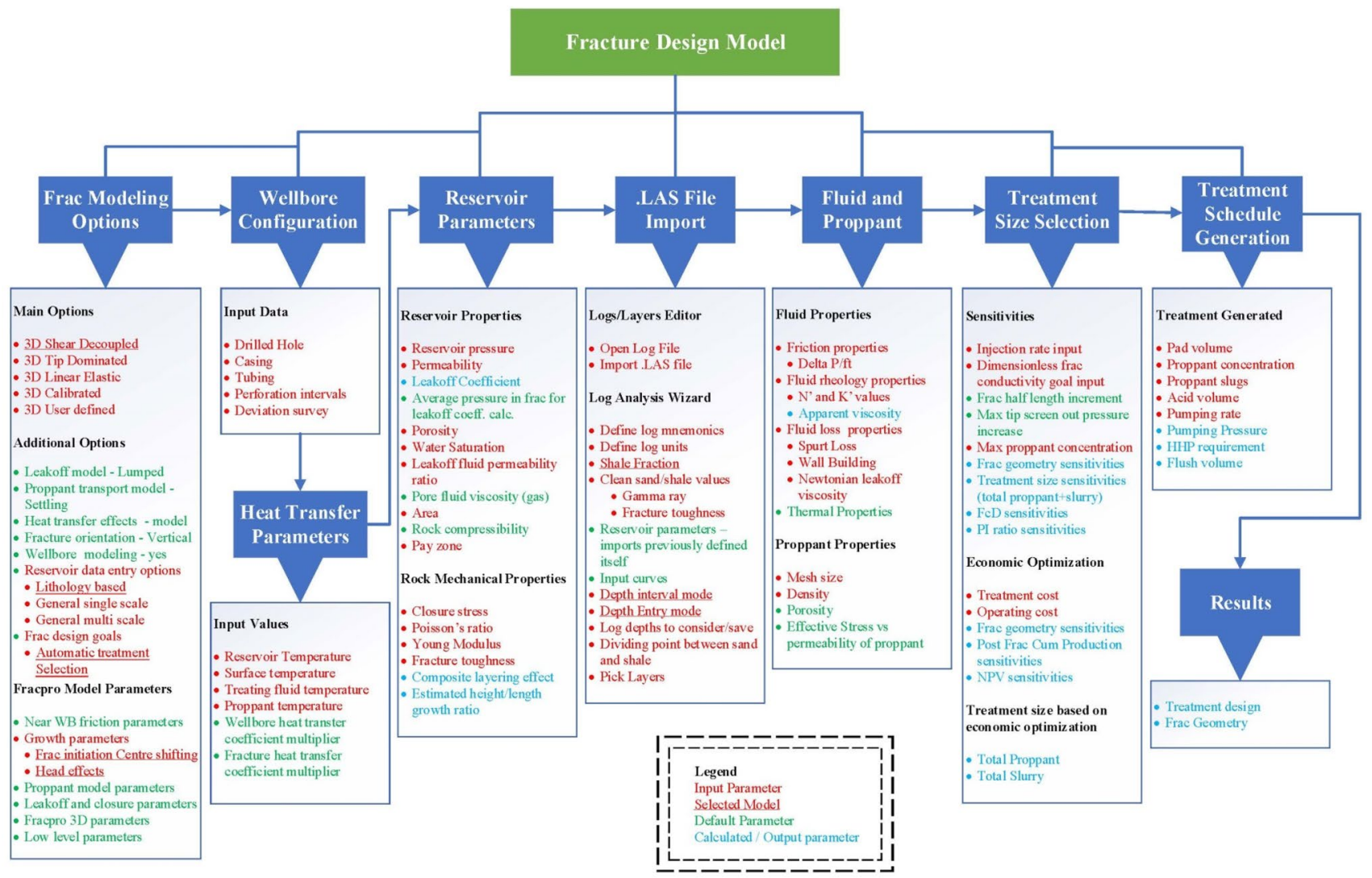

Fig. 1 Detailed process flowchart of hydraulic fracture growth model design

using the process flow shown in Fig. 3. The equations used for each calculation are shown from Eq. 1 to Eq. 9.

\section{a) Barrels of Oil Equivalent (BOE):}

$\mathrm{BOE}(\mathrm{MMBOE})=\frac{\mathrm{Cum} \cdot \mathrm{Gas}(\mathrm{BCF})}{5.8}$

b) Gross Revenues:
N.Revenues $(\$ M)=$ G.Revnues $(\$ M)-[$ G.Revenues $*$ Royalty $(\%)]$

d) OPEX:

$$
\mathrm{OPEX}=\frac{\operatorname{OPEX} \operatorname{Rate}\left(\frac{\$}{\mathrm{BOE}}\right) * \mathrm{BOE}(\mathrm{MBOE})}{1000}
$$

G. Revenues $(\$ M)=\frac{\text { Heating Value }\left(\frac{\mathrm{BTU}}{\mathrm{SCF}}\right) * \operatorname{Gas} \operatorname{Price}\left(\frac{\$}{\mathrm{MMBTU}}\right) * \text { Cum.Gas }(\mathrm{MMSCF})}{1000000}$

c) Net Revenues:

Profit Before Tax $(\$ M)=$ N. Revenue $(\$ M)-\operatorname{OPEX}(\$ M)$

f) Net Profit:

N.Profit $(\$ M)=$ Profit Before Tax $(\$ M)-[$ Profit Before $\operatorname{Tax}(\$ M) * \operatorname{Tax} \%$ ]

\section{g) CAPEX:}

CAPEX $=$ D\&C Cost + Workover + Tangible Costs + Services

h) Discounted Cashflow (For Each Year): 


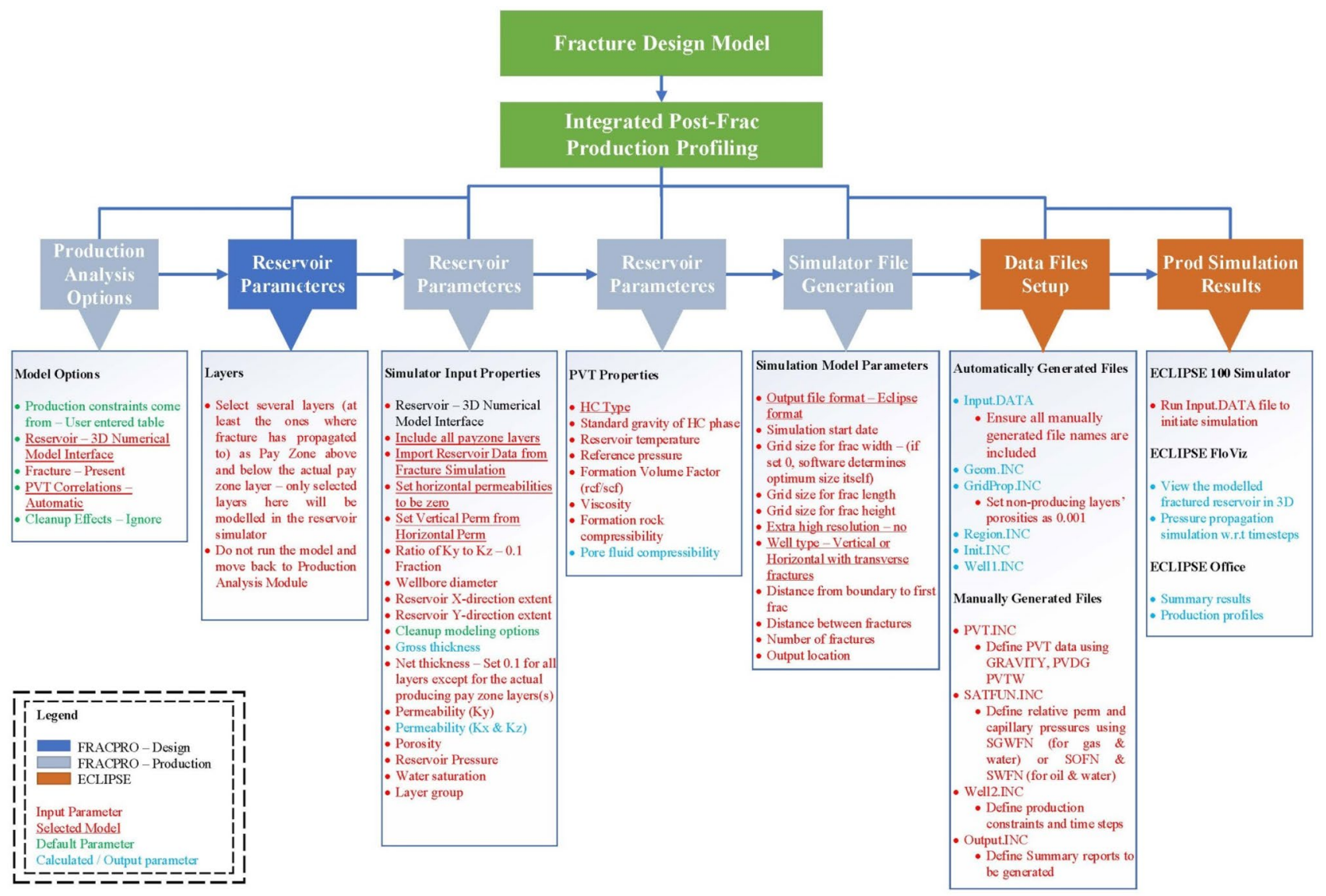

Fig. 2 Detailed process flowchart of integrated approach of post-frac production profiling

Table 2 Case descriptions which were run on the integrated model

\begin{tabular}{llllll}
\hline Case & Wellbore Orientation & $\begin{array}{l}\text { Lateral Sec- } \\
\text { tion }(\mathrm{ft})\end{array}$ & $\begin{array}{l}\text { No. of Fracture } \\
\text { Stages }\end{array}$ & $\begin{array}{l}\text { Fracture Spac- } \\
\text { ing }(\mathrm{ft})\end{array}$ & $\begin{array}{l}\text { Simula- } \\
\text { tion Time } \\
\text { (days) }\end{array}$ \\
\hline Case 1 & Vertical & 0 & 0 & 650 & 1000 \\
Case 2 & Vertical & 0 & 1 & 650 & 1000 \\
Case 3 & Horizontal & 2200 & 3 & 650 & 1000 \\
Case 4 & Horizontal & 3500 & 5 & 650 & 1000 \\
Case 5 & Horizontal & 4800 & 7 & 650 & 1000 \\
Case 6 & Horizontal & 3500 & 7 & 465 & 1000 \\
\hline
\end{tabular}

D.Cashflow $=[$ N.Profit - CAPEX $] *\left[\frac{1}{(1+\text { D.Rate })^{\text {Current Year }- \text { First Year }+0.5}}\right]$

\section{i) Net Present Value (NPV):}

$$
\text { NPV }=\text { Sum of all Discounted Cashflows }
$$




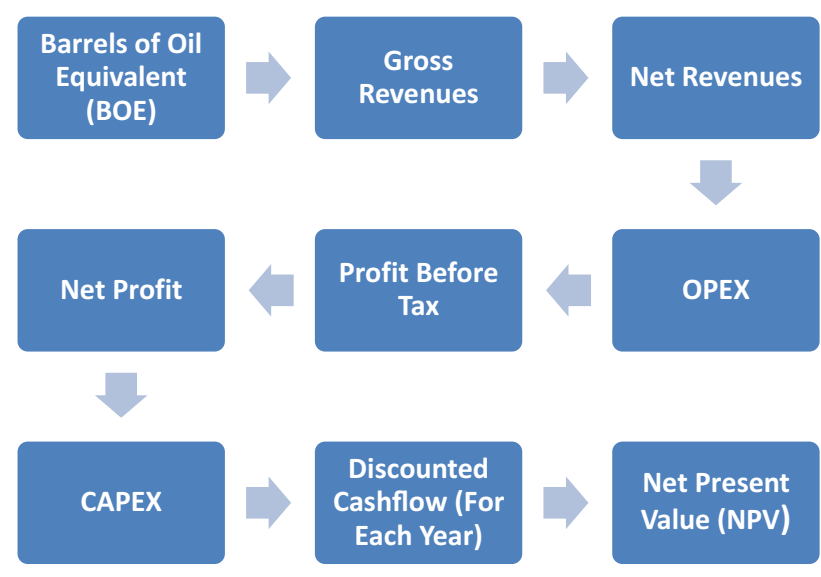

Fig. 3 Process flow for evaluation of NPV

\section{Fracture growth modeling}

The pay zone interval, referred to as the "C Sand" in Fig. 4, is stretched from X394 to X600 feet. C Sand formation is fundamentally a shaly sandstone formation with excessive clay content in it and is characterized by the relatively high radioactivity of the formation, as is evident from the gamma ray log in Fig. 4. It was initially perforated from X394 to X433.

It can be seen from Fig. 4 that B sand sandstone formation lies just above $C$ Sand leaving $C$ Sand with no overlying barrier for hydraulic fracture containment. This definitely will have a noteworthy impact on the fracture geometry and proppant concentration placement. An adequate underlying shale barrier is present below the pay zone, which will prove crucial in containing the fracture lower height.

The information about the layers of the well from surface to total depth (TD) is inserted in the fracture model by importing the Log ASCII Standard (LAS) file (Fig. 5).

The gamma ray log was used for layers identification as it is an excellent lithology indicator. Subsequently, gamma ray values of clean sandstone and clean shale are defined, so that the software may distinguish between different layers based upon those values (Fig. 6).

Permeabilities were then set for each layer, and the "pay zone" is selected (highlighted in yellow in Fig. 7); the middle of this selected pay zone layer is where the fracture should ideally initiate in the growth model.

Fracture fluid to be used during the fracture treatment execution is selected from the internal fluid libraries containing numerous fluid systems and proppants from the major service companies.
Fig. 4 Pay zone interval of Well 01 indicated by $\operatorname{logs}$

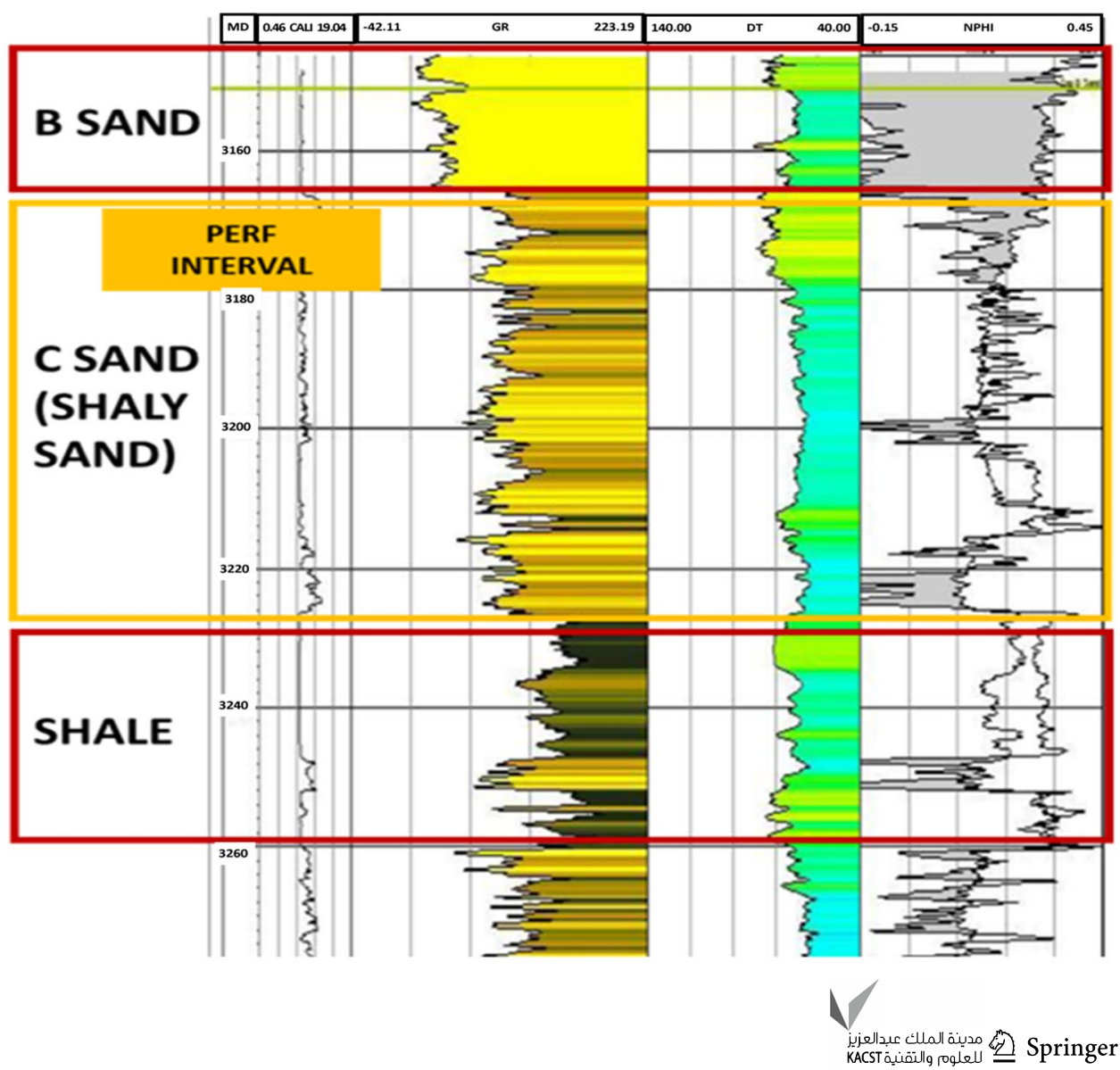




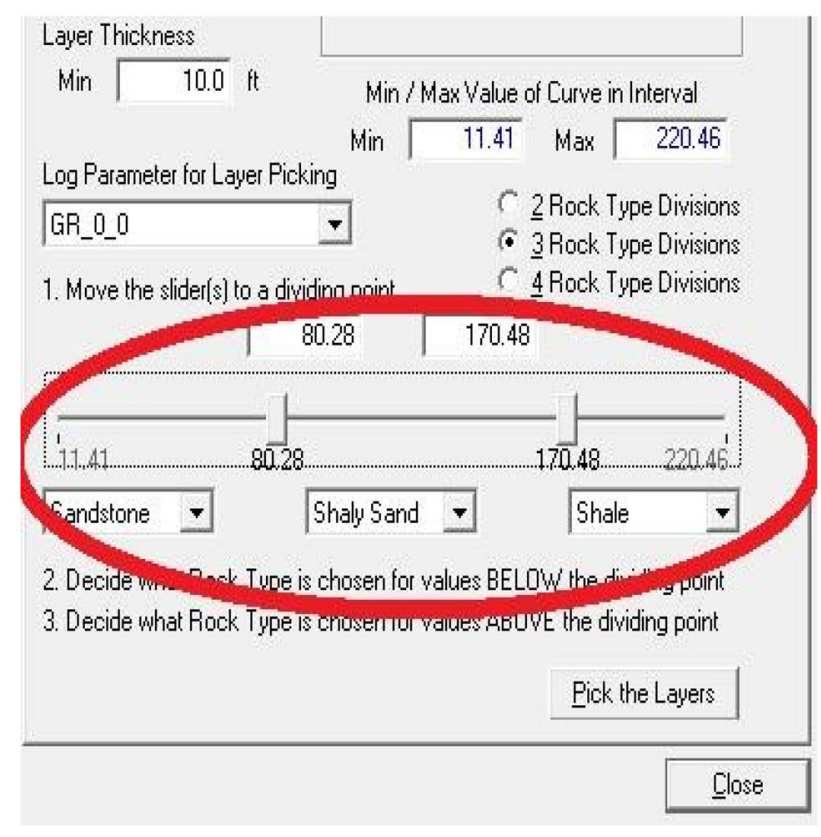

Fig. 5 logs LAS file imported in fracture growth model

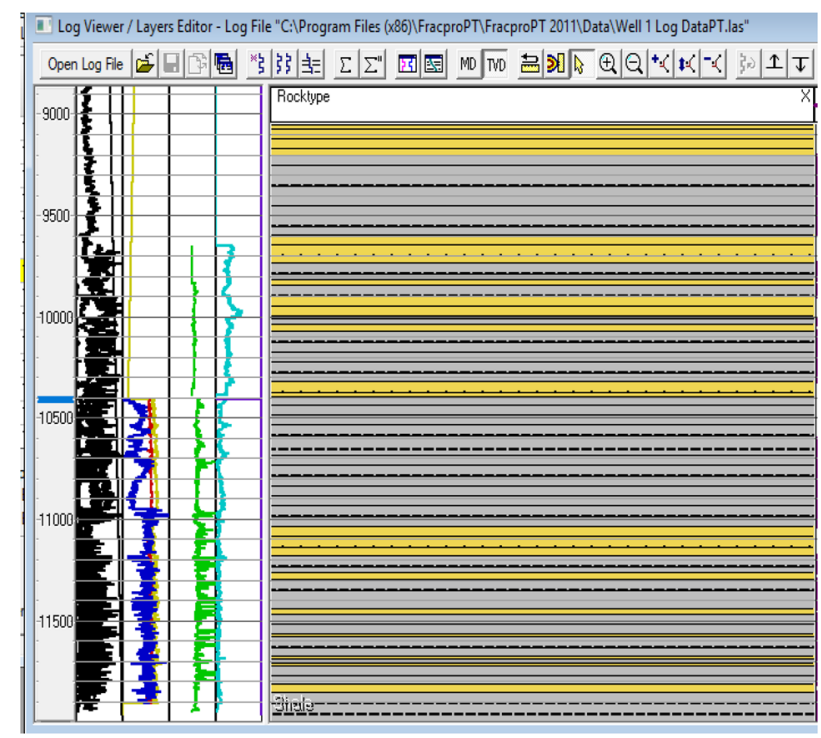

Fig. 6 Lithology identification based on gamma ray values

Fracturing fluids and proppants are selected on the basis of following parameters:

- Reservoir compatibility

- Reservoir temperature

- Minimum required apparent viscosity

- Flowback capability

- Average permeability

- Reservoir pressure
- Closure stress

- Economics

Since the subject hydraulic fracture treatment was designed for a low-permeability tight sand formation, the target was a higher fracture length instead of a wider fracture width. Therefore, 20/40 mesh proppant, a smaller proppant size, was selected for the treatment to achieve the mentioned objective. Moreover, the selected proppant should be able to hold the fractures open without collapsing, after they have been created during the treatment; therefore, proppant's compressive strength should be greater than the difference of formation's closure stress and reservoir pressure.

The foremost consideration in the selection of a fracturing fluid is its ability of retaining the required viscosity at the reservoir temperature. YF100.1HTD fluid system was utilized in the designing of the subject hydraulic fracture treatment. YF100.1HTD is a high-temperature water-based fluid system composed of a refined guar gelling agent crosslinked by a borate cross-linker, designed to be effective up to $350^{\circ} \mathrm{F}$. These fluids are very viscous fracturing fluids, owing to the cross-linking agents used to dramatically increase the effective molecular weight of the polymer, thereby increasing the viscosity of the solution.

Achievable injection rate value is inserted in the software, which depends upon the maximum surface pressures the pumps can handle. Dimensionless fracture conductivity and proppant concentration are set here at a user-defined goal. Subsequently, the software provides a tool to investigate the sensitivities of hydraulic fracture growth behavior so that a proper pump rate and maximum treatment size can be selected, prior to simulation. It allows to determine how large a job needs to be pumped (in terms of fluid volume and proppant concentration) in order to obtain a specified hydraulic fracture dimension, while keeping the dimensionless conductivity set at a user-defined goal, as evident in Fig. 8. However, the maximum frac length selected could here be 330 feet, owing to the local technical pumping limits of pumping proppant. This, however, does not necessarily mean that this treatment will result in a fracture limited to 330 feet half length in the simulation.

As the final step in the entire design process, the actual pump schedule along with the treatment totals necessary to achieve the required conductivity distribution in the hydraulic fracture (as function of the distance from the wellbore) that corresponds to the selected hydraulic fracture treatment size is generated (Fig. 9). Designed fracture geometry and its dimensions are given in Fig. 10 and Table 3. Designed fracture dimensions with respect to increasing fracture length are given in Fig. 11.

It may be noted in Figs. 10 and 11 that the effects of failed fracture height containment are because of the absence of an overlying barrier. Fortunately, B Sand was proved to be 


\begin{tabular}{|c|c|c|c|c|c|c|c|c|c|c|c|c|c|c|}
\hline \multicolumn{14}{|c|}{ Reservoir Parameters - F9 } & $\times$ \\
\hline \multirow{2}{*}{\multicolumn{15}{|c|}{$\begin{array}{l}\text { Layers | Rock Properties | Additional Properties | Rock Library | } \\
\text { Reservoir Data-Entry Options } \\
\text { \& Lithology-Based } ~ \text { General Multi-Scale } \sim \text { General Single Scale }\end{array}$}} \\
\hline & & & & & & & & & & & & & & \\
\hline & $\begin{array}{l}\text { Depth } \\
\text { TVD } \\
\text { (ft) }\end{array}$ & $\begin{array}{l}\text { Depth } \\
\text { MD } \\
\text { (it) }\end{array}$ & $\begin{array}{c}\text { Layer } \\
\text { Thickness } \\
\text { [ft] }\end{array}$ & Rock Type & $\begin{array}{l}\text { Pore Fluid } \\
\text { Permeability } \\
(\mathrm{mD})\end{array}$ & $\begin{array}{l}\text { Leakoff } \\
\text { Coefficient } \\
\text { (ft/min's] }\end{array}$ & $\begin{array}{l}\text { Stress } \\
\text { [psi] }\end{array}$ & $\begin{array}{c}\text { Young's } \\
\text { Modulus } \\
\text { (psi) }\end{array}$ & $\begin{array}{l}\text { Poisson's } \\
\text { Ratio }\end{array}$ & $\begin{array}{l}\text { Fracture } \\
\text { Toughness } \\
\text { [psi in 1\%] }\end{array}$ & $\begin{array}{l}\text { Composite } \\
\text { Layering } \\
\text { Effect }\end{array}$ & $\begin{array}{l}\text { Est. } \\
\text { Ht/Len } \\
\text { Growth }\end{array}$ & $\begin{array}{l}\text { Pay } \\
\text { Zane }\end{array}$ & 4 \\
\hline 205 & 10.124 .1 & 10.124 .1 & 50.0 & Shale & $5.0000 E-04$ & $2.2694 \mathrm{E}-04$ & 9642 & $6.00 e+06$ & 0.250 & $2.0 e+03$ & 25.00 & 0.25 & $\square$ & \\
\hline 206 & $10,174.1$ & $10,174.1$ & 50.0 & Shale & $5.0000 \mathrm{E}-04$ & $2.2694 \mathrm{E}-04$ & 9689 & $6.00 e+06$ & 0.250 & $2.0 e+03$ & 25.00 & 0.25 & $\square$ & \\
\hline 207 & 10.224 .1 & $10,224.1$ & 50.0 & Shale & $5.0000 E-04$ & $2.2694 \mathrm{E}-04$ & 9737 & $6.00 e+06$ & 0.250 & $2.0 e+03$ & 25.00 & 0.25 & $\square$ & \\
\hline 208 & 10.274 .1 & $10,274.1$ & 47.3 & Shale & $5.0000 \mathrm{E}-04$ & $2.2694 \mathrm{E}-04$ & 9783 & $6.00 e+06$ & 0.250 & $2.0 e+03$ & 25.00 & 0.25 & $\square$ & \\
\hline 209 & $10,321.5$ & $10,321.5$ & 50.0 & Sandstone & $5.0000 \mathrm{E}-01$ & $6.1971 \mathrm{E}-04$ & 8277 & $5.00 e+06$ & 0.200 & $1.0 \mathrm{e}+03$ & 25.00 & 0.25 & $\square$ & \\
\hline 210 & $10,371.5$ & $10,371.5$ & 22.5 & Sandstone & $5.0000 \mathrm{E}-01$ & $6.1971 \mathrm{E}-04$ & 8306 & $5.00 e+06$ & 0.200 & $1.0 \mathrm{e}+03$ & 25.00 & 0.25 & $\bar{\square}$ & \\
\hline 211 & $10,394.0$ & $10,394.0$ & $40.8:$ & Shaly Sand & $1.5000 \mathrm{E}-01$ & $6.1404 \mathrm{E}-04$ & 9373 & $5.50 e+06$ & 0.250 & $1.8 \mathrm{e}+03$ & 1.00 & 1.00 & 可 & \\
\hline 212 & $10,434.8$ & $10,434.8$ & 50.0 & Shaly Sand & $1.5000 \mathrm{E}-01$ & $6.1404 \mathrm{E}-04$ & 9414 & $5.50 e+06$ & 0.250 & $1.8 \mathrm{e}+03$ & 25.00 & 0.25 & $\square$ & \\
\hline 213 & 10.484 .8 & $10,484.8$ & 50.0 & Shaly Sand & $1.5000 \mathrm{E}-01$ & $6.1404 \mathrm{E}-04$ & 9459 & $5.50 e+06$ & 0.250 & $1.8 e+03$ & 25.00 & 0.25 & $\square$ & \\
\hline 214 & 10.534 .8 & 10.534 .8 & 50.0 & Shaly Sand & $1.5000 E-01$ & $6.1404 \mathrm{E}-04$ & 9504 & $5.50 e+06$ & 0.250 & $1.8 \mathrm{e}+03$ & 25.00 & 0.25 & $\square$ & \\
\hline 215 & 10.584 .8 & 10.584 .8 & 15.2 & Shaly Sand & $1.5000 \mathrm{E}-01$ & $6.1404 \mathrm{E}-04$ & 9533 & $5.50 e+06$ & 0.250 & $1.8 e+03$ & 25.00 & 0.25 & $\square$ & \\
\hline 216 & $10,600.0$ & $10,600.0$ & 84.8 & Shale & $5.0000 E-04$ & $2.2694 \mathrm{E}-04$ & 10110 & $6.00 \mathrm{e}+06$ & 0.250 & $2.0 \mathrm{e}+03$ & 25.00 & 0.25 & $\square$ & $\square$ \\
\hline 217 & 10.684 .8 & 10.684 .8 & $50.0:$ & Shale & $5.0000 \mathrm{E}-04$ & $2.2694 \mathrm{E}-04$ & 10174 & $6.00 \mathrm{e}+06$ & 0.250 & $2.0 \mathrm{e}+03$ & 25.00 & 0.25 & $\square$ & \\
\hline 218 & 10.734 .8 & 10.734 .8 & 50.0 & Shale & $5.0000 E-04$ & $2.2694 \mathrm{E}-04$ & 10222 & $6.00 e+06$ & 0.250 & $2.0 \mathrm{e}+03$ & 25.00 & 0.25 & $\square$ & $\nabla$ \\
\hline \multirow{3}{*}{\multicolumn{3}{|c|}{$\left[\begin{array}{l}\text { Depth Entry Mode } \\
\sim \text { Enter TVD } \\
\sim \text { Enter MD }\end{array}\right]$}} & - Fluid Loss & Entry Mode & & & \multicolumn{6}{|c|}{ Perforations } & & \\
\hline & & & * Enter P & Permeability & Set Litholog: & Permeability & \multicolumn{6}{|c|}{ Depth to Top of Perfs $\longdiv { 1 0 , 3 9 4 } ( \mathrm { ft } )$} & & \\
\hline & & & C Enter L & Leakoff Coefficient & & & \multirow{2}{*}{\multicolumn{6}{|c|}{ 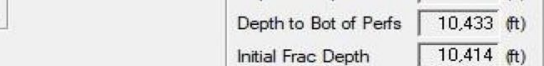 }} & & \\
\hline \multirow{2}{*}{\multicolumn{3}{|c|}{ Reservoir Temperature }} & & & & & & & & & & & & \\
\hline & & & $\overline{336}\left({ }^{\circ} \mathrm{F}\right)$ & & & & & gs/Layers & Editor & Layer Displ & & Next & & \\
\hline
\end{tabular}

Fig. 7 Pay zone selection in reservoir parameters input window of design module

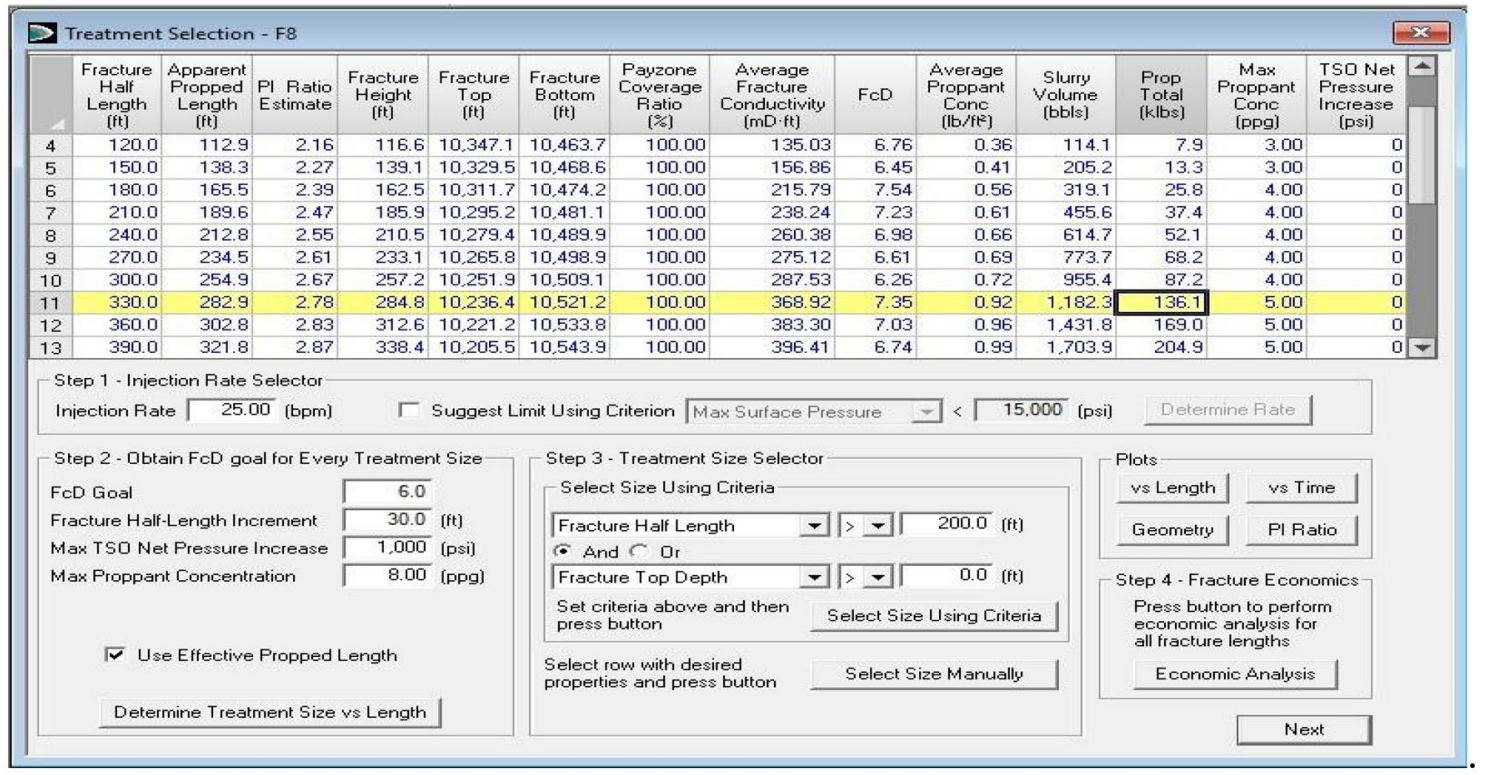

Fig. 8 Sensitivities of pump rate and treatment size with respect to target fracture length

dry in earlier testing and does not pose a significant threat to the fracture treatment. Due to same reason, it may also be noted from Fig. 10 that the proppant concentration against B Sand is greater than the concentration against perforations (denoted by a blue block) in C Sand. Ideally, proppant concentration against the perforations should be the highest as the fracture is being assumed to initiate at the middle of perforation interval in the fracture model.

\section{Integrated approach: coupling of fracture model and reservoir simulation model}

The integrated approach presented in this study effectively integrates the output from the fracture growth model (enhanced permeabilities, fracture dimensions, fracture conductivities, leakoff profile) and the fracture conductivity model into a reservoir simulation model, in a bid to 


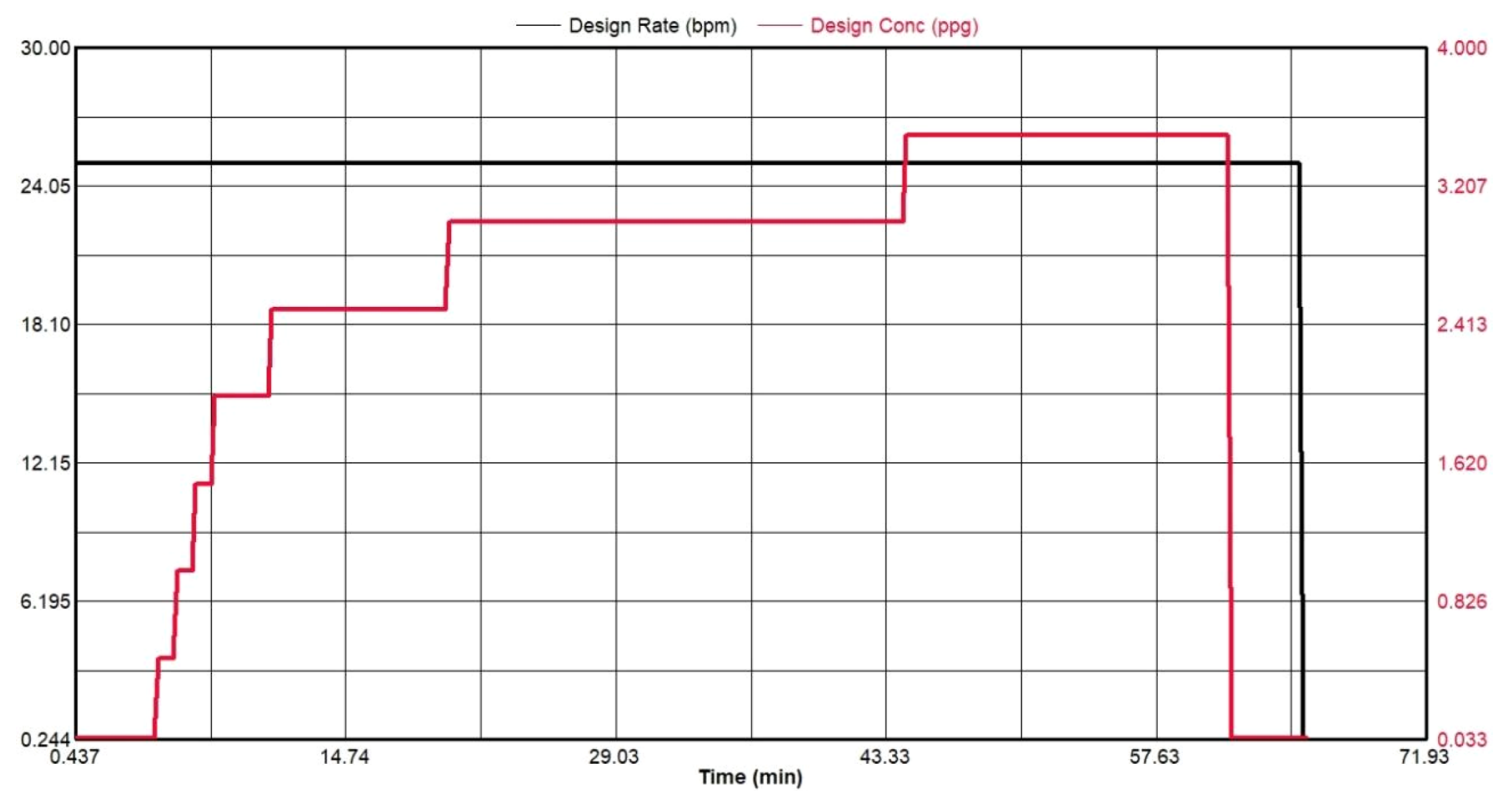

Fig. 9 Design treatment (rate and concentration) plot against time
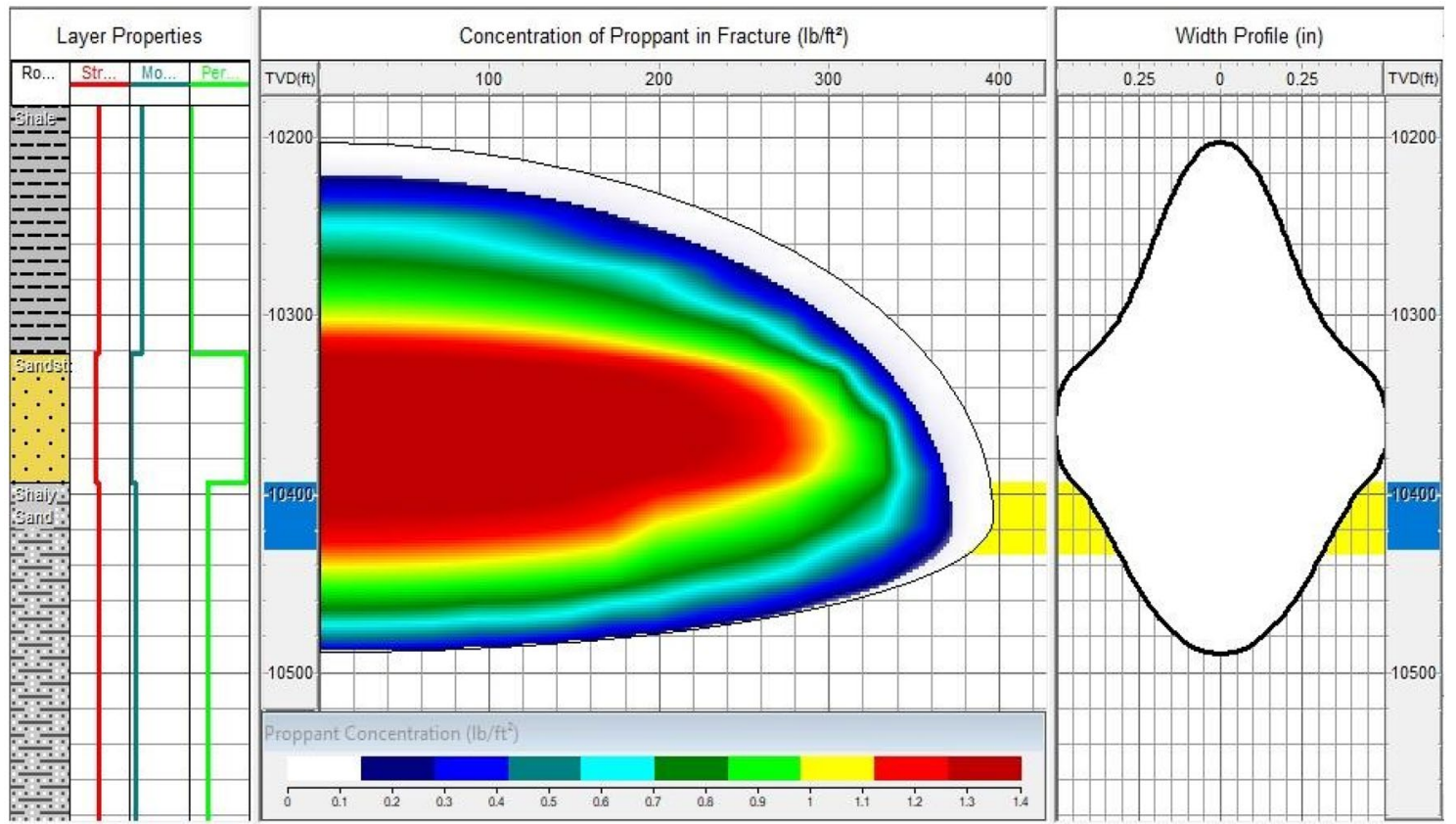

Fig. 10 Designed fracture geometry

effectively model the behavior of a hydraulically fractured reservoir.

The spatial variation in the fracture growth model was converted into a gridded rectangular geometry for the reservoir simulator. The information about the distribution of the proppant concentration in the fracture as well as fracture width variation was translated into the permeabilities and conductivities of the fracture grid blocks using a tool in the FRACPRO fracture simulator, which uses the conductivity model to generate data files for ECLIPSE 100 reservoir simulator. These data files are used as input files for the ECLIPSE reservoir simulator in which Local Grid Refinement (LGR) is used in the vicinity of the stimulated well to input fracture dimensions. Initial properties in each grid 
Table 3 Fracture dimensions of simulated fracture treatment in Well 01

\begin{tabular}{lll}
\hline Fracture length (ft) & 397.6 & $\mathrm{ft}$ \\
\hline Propped length & 363.0 & $\mathrm{ft}$ \\
Total fracture height & 287.5 & $\mathrm{ft}$ \\
Total propped height & 262.5 & $\mathrm{ft}$ \\
Fracture top depth & $\mathrm{X} 202.5$ & $\mathrm{ft}$ \\
Fracture bottom depth & $\mathrm{X} 490.0$ & $\mathrm{ft}$ \\
Avg. fracture width & 0.531 & $\mathrm{in}$ \\
Avg. proppant concentration & 1 & $\mathrm{lb} / \mathrm{ft}^{3}$ \\
Dimensionless conductivity & 11.177 & \\
Clean volume & 1497.7 & $\mathrm{bbls}$ \\
Slurry volume & 1630.4 & $\mathrm{bbls}$ \\
Total proppant & 156.5 & $\mathrm{Klbs}$ \\
Flush volume & 93.0 & $\mathrm{bbls}$ \\
\hline
\end{tabular}

block are initialized using the data entered in the fracture growth model.

The resulting model incorporates the important physics of fluid flow through fractures in the reservoir simulation model by taking the input of simulated fracture parameters directly from the designed fracture growth model. Therefore, production analysis of the fracture treatment performed from this approach is representative of the actual processes occurring in the reservoir.

The resulting integrated model was used to perform sensitivities for the six cases mentioned in Table 2. Permeability variations between different layers of reservoir formations for the cases are also shown in Fig. 12.
Vertical wells are to be modeled in quarter symmetry. This means that only one quarter of the total drainage area will be explicitly modeled for vertical wells. Similarly, horizontal wells are to be modeled in half symmetry, meaning that half of the total drainage will be explicitly modeled for horizontal wells. Therefore, predicted production simulation results will need to be adjusted, quadrupled for vertical wells and doubled for horizontal wells to get correct production estimates. The production profiles obtained are subsequently used to determine the most profitable case, using an economic model.

Pressure transient propagation, gas rates and cumulative gas production for different cases are given in Figs. 13, 14 and 15. Results from the analysis of all cases are summarized in Table 4. Results of the economic modeling are presented in Table 5. Economic comparison of the six cases is also plotted in Fig. 16.

Cases depict the importance of hydraulic fracturing and horizontal well drilling for tight formations as vertical well without any hydraulic fracturing treatment (Case 1) resulted in overall negative NPV and vertical well with one fracture stage (Case 2) resulted in the lowest positive NPV as compared to all cases of horizontal well (Cases 3 to 6). Cases 3 to 5 further confirm that the cumulative gas production increased with the number of fracture stages in the well and lateral length, while the fracture spacing remained constant. It should be noted that the fracture spacing of $650 \mathrm{ft}$ in Cases 3 to 5 was selected observing the propagation of the pressure pulse between consecutive stages in various simulations, making sure the stages come in communication with each other to effectively drain the space between them. Further reducing the fracture spacing for a given horizontal length,

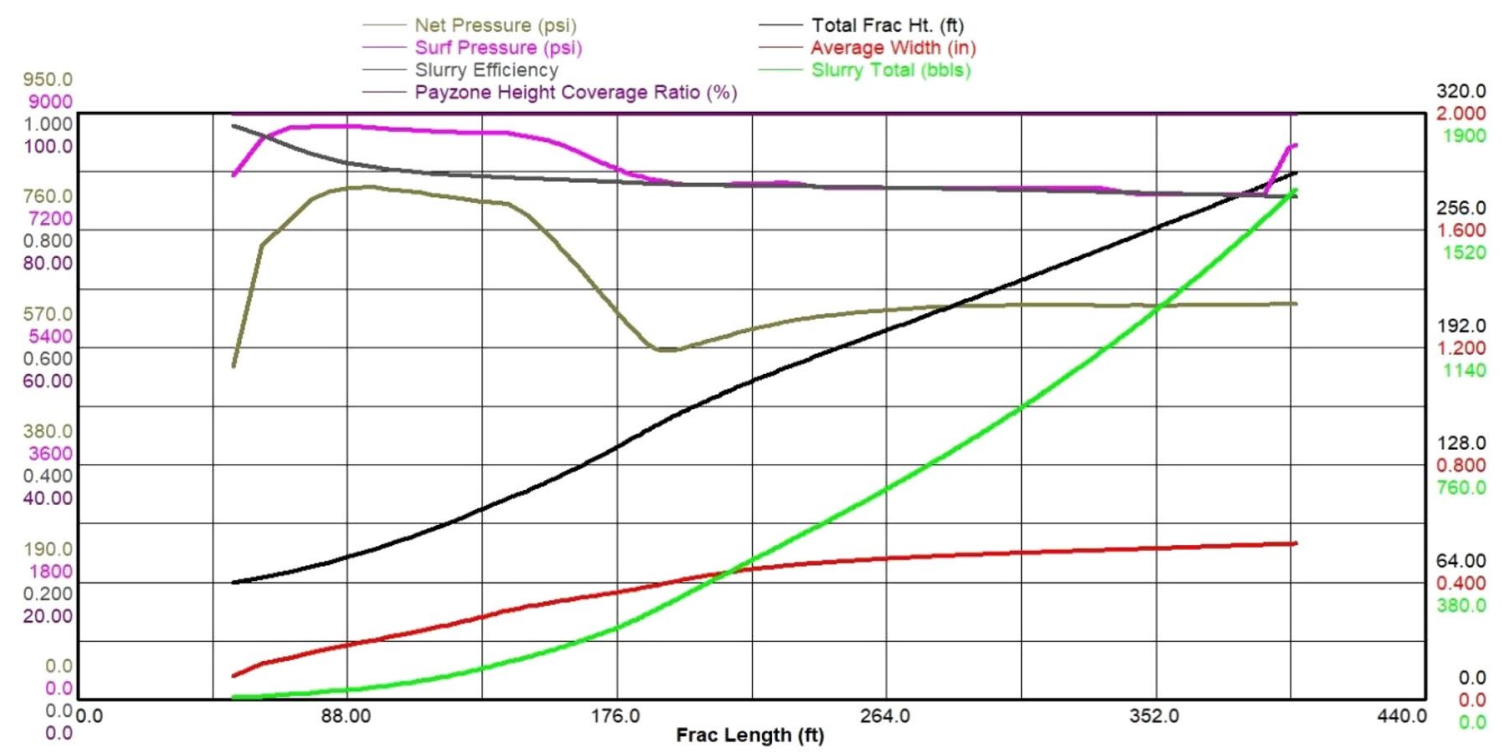

Fig. 11 Designed fracture dimensions with respect to increasing fracture length 


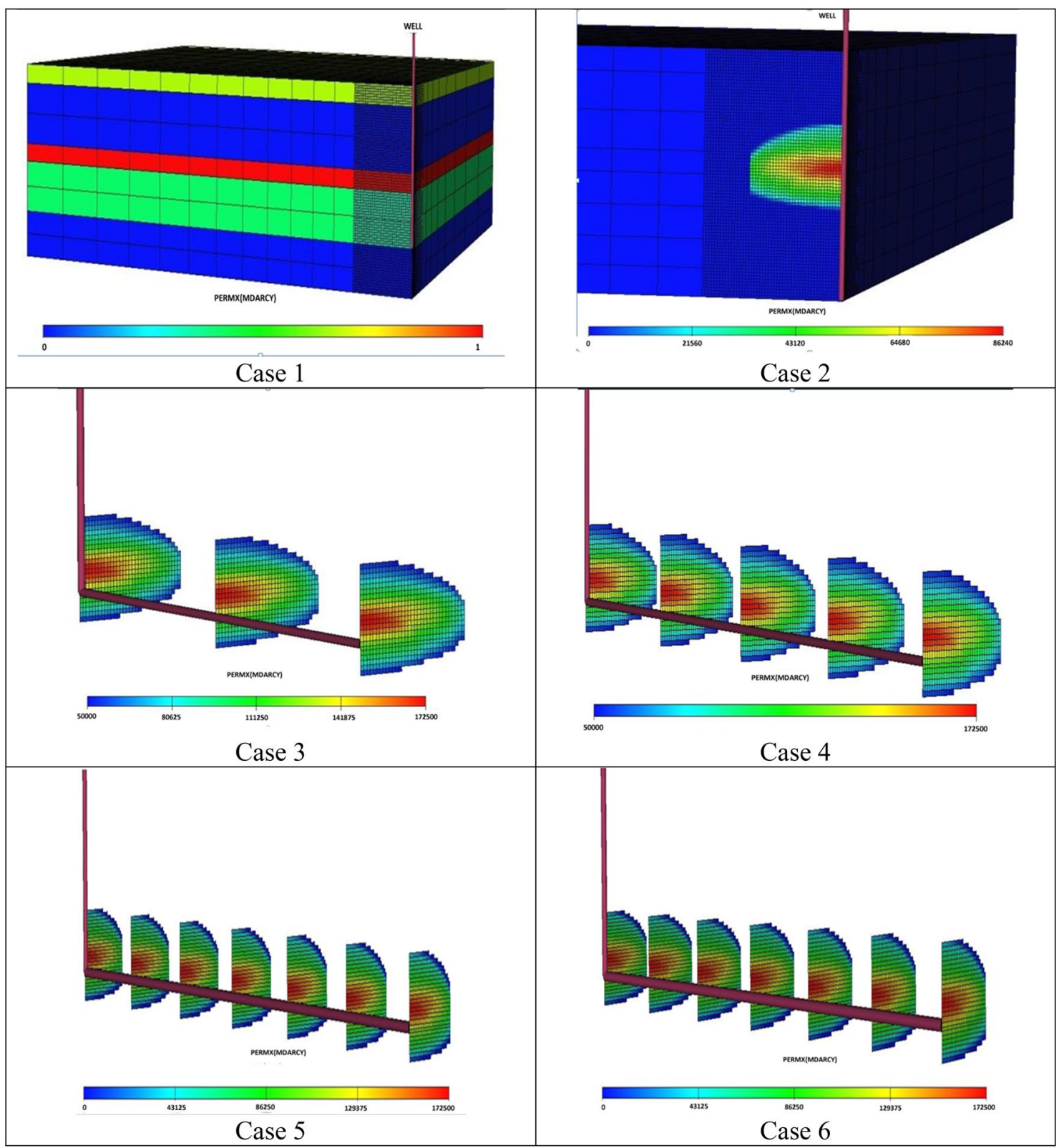

Fig. 12 Permeability variations translated into the grid blocks based on proppant concentrations contained in induced fractures for Case 1, Case 2, Case 3 and Case 4

as in Case 6, did not notably increase the cumulative gas volumes.

From Table 5, it can be observed that the most optimum hydraulic fracture treatment for Well 01 is proved to be Case 5 with an NPV of $\$ 12.2 \mathrm{M}$. In this case, the well was completed with a lateral length of $4800 \mathrm{ft}$ with a total of seven fracture stages. The well was produced with an average production rate (of first 30 days) of $30.3 \mathrm{MMSCF} / \mathrm{D}$. It is also worth mentioning that although Case 5 has a higher CAPEX cost due to multiple fracture stages and additional lateral length and higher OPEX cost due to higher water production rate, it still has the highest NPV. This strengthens the argument that the costs associated in developing tight formations relating to the number of fracture stages, increasing lateral lengths and higher water production rates are not linearly proportional and require simulations to be run so that caseto-case comparison can be performed. 


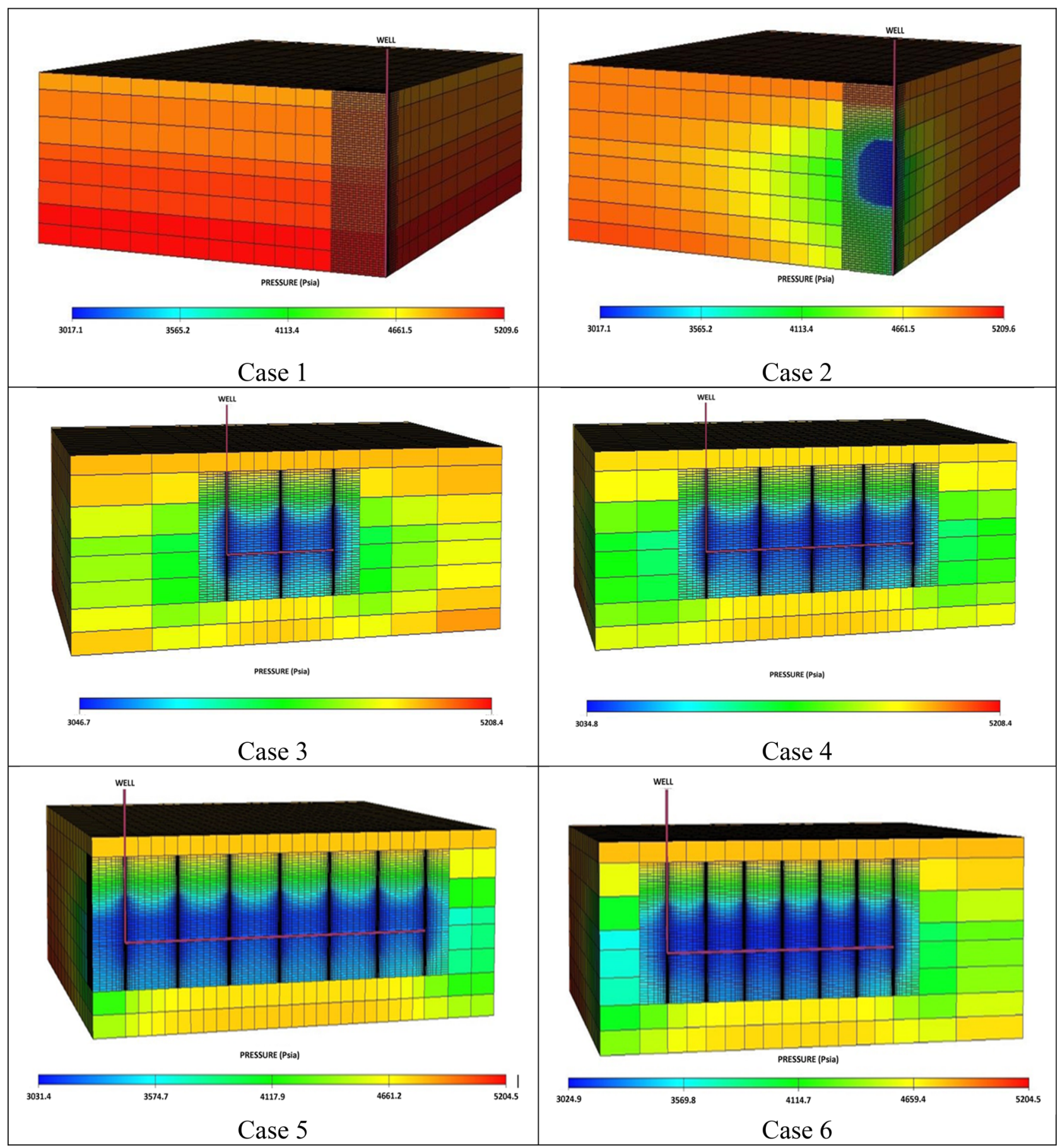

Fig. 13 Screen capture of pressure transient propagation simulation after 1000 days of production for Case 1, Case 2, Case 3, Case 4, Case 5 and Case 6

The NPV of Case 6 is lower than Case 4 due to additional costs of higher number of fracture stages and a relatively lower increase in the cumulative gas production volumes. This shows the importance of designing optimum fracture spacing for a particular lateral length to lower the overall cost incurred.

\section{Conclusions}

Unconventional resource development in Pakistan is in its nascent stages. Efficient methodologies related to its exploration and production are needed to untapped this large resources in the most convenient manner. The technological 


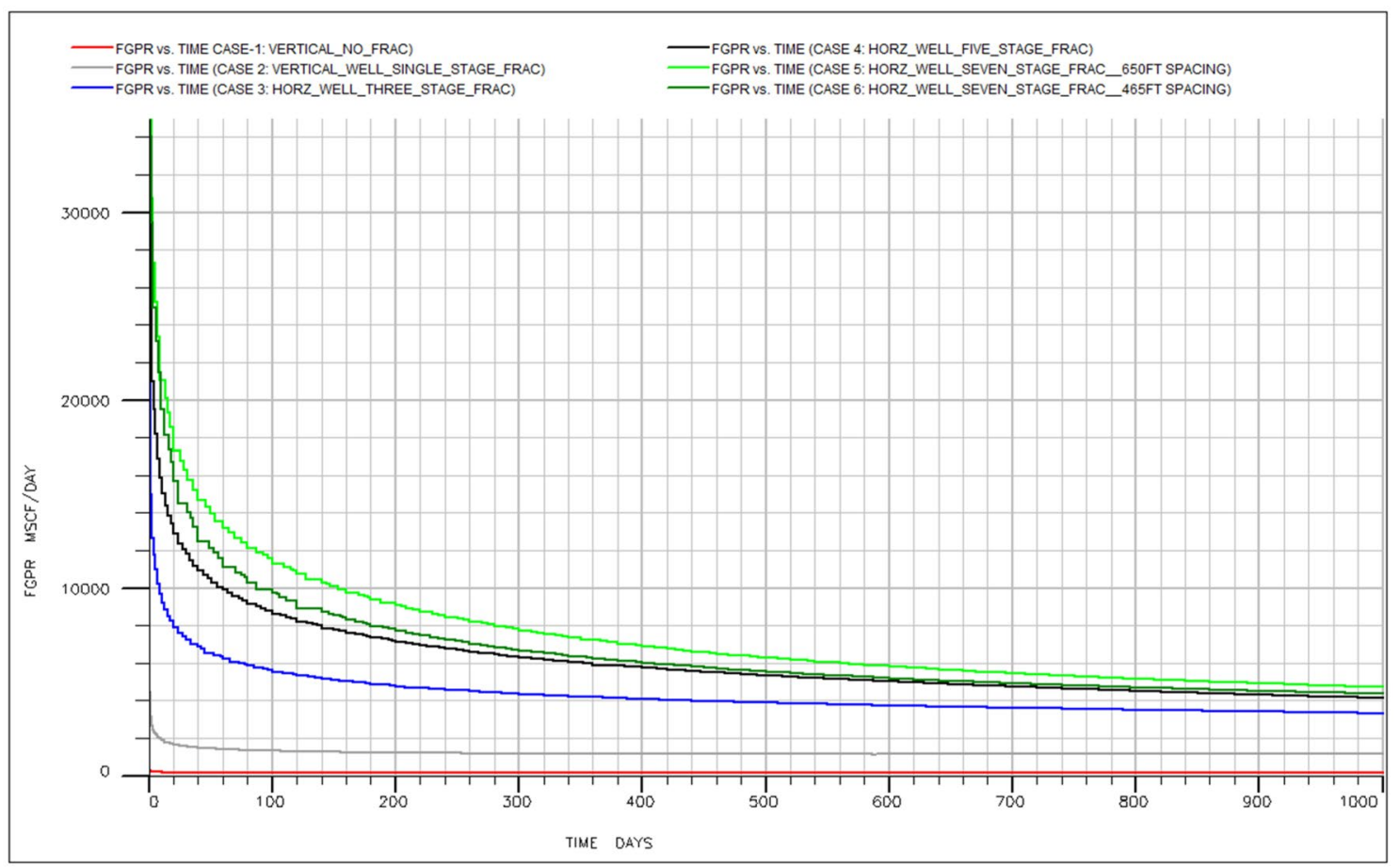

Fig. 14 Production gas rates for all six cases. (Cases 1, 2, 3, 4, 5 and 6 represented by red, gray, blue and black, brown and green, respectively)

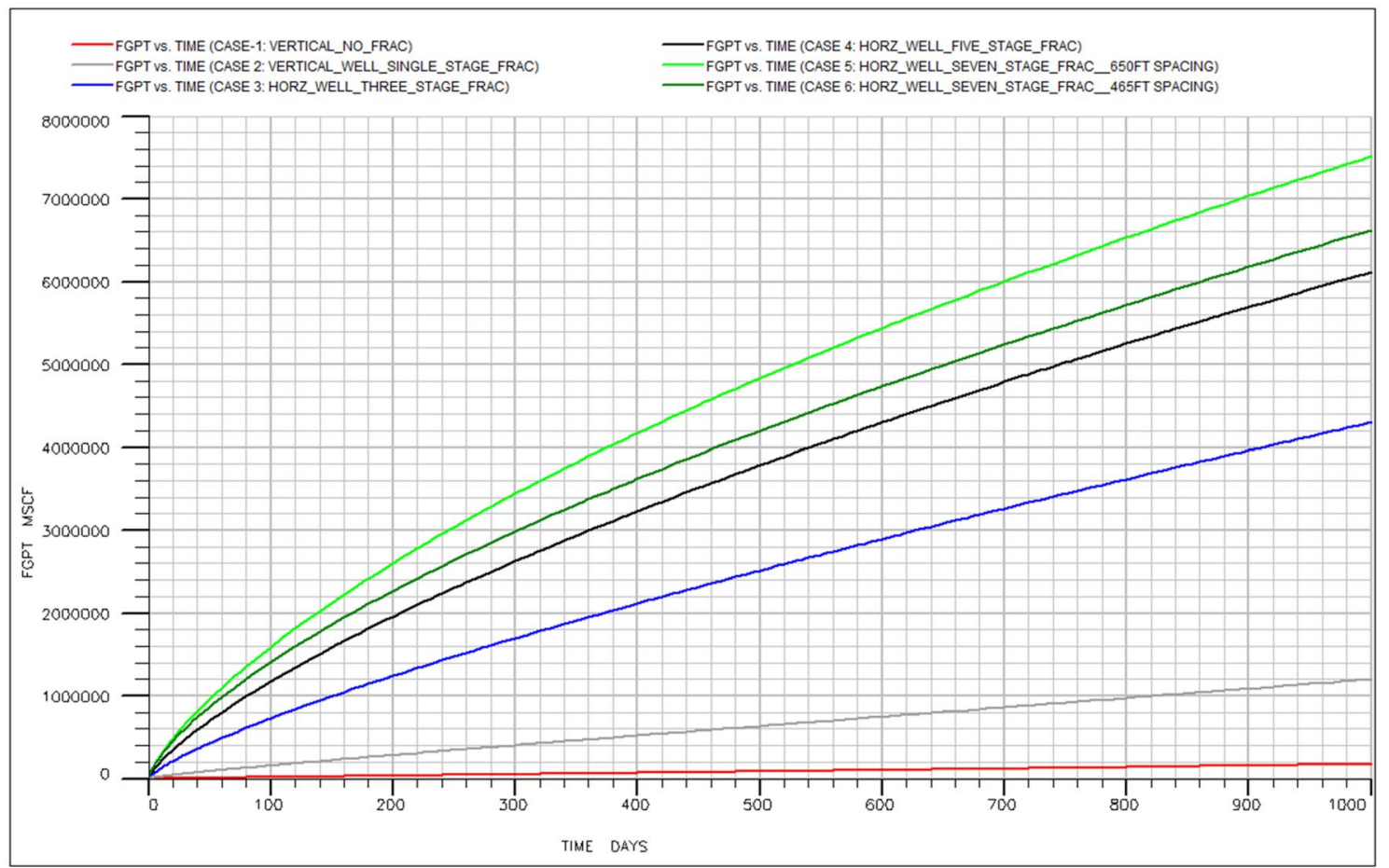

Fig. 15 Cumulative gas rates for all six cases after 1000 days. (Cases 1, 2, 3, 4, 5 and 6 represented by red, gray, blue and black, brown and green, respectively) 
Table 4 Simulation results summary of the six cases (adjusted by symmetry factors)

\begin{tabular}{|c|c|c|c|c|c|c|}
\hline & $\begin{array}{l}\text { Case } 1 \\
\text { Vertical } \\
\text { Un-Stimulated }\end{array}$ & $\begin{array}{l}\text { Case } 2 \\
\text { Vertical } \\
\text { Single-frac }\end{array}$ & $\begin{array}{l}\text { Case } 3 \\
\text { Lateral 2220ft } \\
\text { Three-Stage }\end{array}$ & $\begin{array}{l}\text { Case } 4 \\
\text { Lateral } 3500 \mathrm{ft} \\
\text { Five-Stage }\end{array}$ & $\begin{array}{l}\text { Case } 5 \\
\text { Lateral } 4800 \mathrm{ft} \\
\text { Seven-Stage }\end{array}$ & $\begin{array}{l}\text { Case } 6 \\
\text { Lateral } \\
3500 \mathrm{ft} \\
\text { Seven-Stage }\end{array}$ \\
\hline $\begin{array}{l}\text { Avg. Gas Rate } \\
\text { 30 Days (MMSCF/D) }\end{array}$ & 0.22 & 9.7 & 16.3 & 26.1 & 30.3 & 26.85 \\
\hline $\begin{array}{l}\text { Avg. Water Rate } \\
30 \text { Days }(\text { STB/D) }\end{array}$ & 7.1 & 262 & 439.7 & 702.3 & 818.3 & 726.7 \\
\hline $\begin{array}{l}\text { Total Gas Prod } \\
1000 \text { Days (BSCF) }\end{array}$ & 0.70 & 4.8 & 8.6 & 12.2 & 15 & 13.3 \\
\hline $\begin{array}{l}\text { Total Water Prod } \\
1000 \text { Days (STB) }\end{array}$ & 6320 & 94,128 & 187,576 & 280,206 & 350,106 & 303,842 \\
\hline
\end{tabular}

Table 5 Comparative economic analysis of each case for production up to 1000 days

\begin{tabular}{|c|c|c|c|c|c|c|c|c|c|c|}
\hline Case & $\begin{array}{l}\text { Cum. Gas Prod } \\
\text { BSCF }\end{array}$ & $\begin{array}{l}\text { Cum. BOE } \\
\text { MMBOE }\end{array}$ & $\begin{array}{l}\text { Gross Revenue } \\
\$ \mathrm{M}\end{array}$ & $\begin{array}{l}\text { Royalty } \\
\$ M\end{array}$ & $\begin{array}{l}\text { CAPEX } \\
\$ M\end{array}$ & $\begin{array}{l}\text { OPEX } \\
\$ M\end{array}$ & $\begin{array}{l}\text { Profit Before Tax } \\
\$ M\end{array}$ & $\begin{array}{l}\text { Tax } \\
\$ M\end{array}$ & $\begin{array}{l}\text { Net Profit } \\
\$ M\end{array}$ & $\begin{array}{l}\text { NPV } \\
\$ M\end{array}$ \\
\hline 1 & 0.7 & 0.12 & 3.87 & 0.48 & 7.00 & 0.80 & 2.58 & 1.03 & 1.55 & 5.3 \\
\hline 2 & 4.8 & 0.83 & 26.28 & 3.29 & 8.29 & 5.44 & 17.56 & 7.02 & 10.53 & 1.3 \\
\hline 3 & 8.6 & 1.48 & 44.53 & 5.57 & 12.77 & 9.21 & 29.75 & 11.9 & 17.85 & 3.5 \\
\hline 4 & 12.2 & 2.10 & 64.95 & 8.12 & 14.75 & 13.44 & 43.39 & 17.36 & 26.04 & 9.0 \\
\hline 5 & 15 & 2.58 & 74.81 & 9.35 & 17.74 & 15.48 & 49.98 & 19.99 & 29.99 & 12.2 \\
\hline 6 & 13.3 & 2.30 & 66.61 & 8.33 & 15.74 & 13.78 & 44.50 & 17.80 & 26.70 & 8.5 \\
\hline
\end{tabular}

Fig. 16 Column chart analysis of NPVs of each case

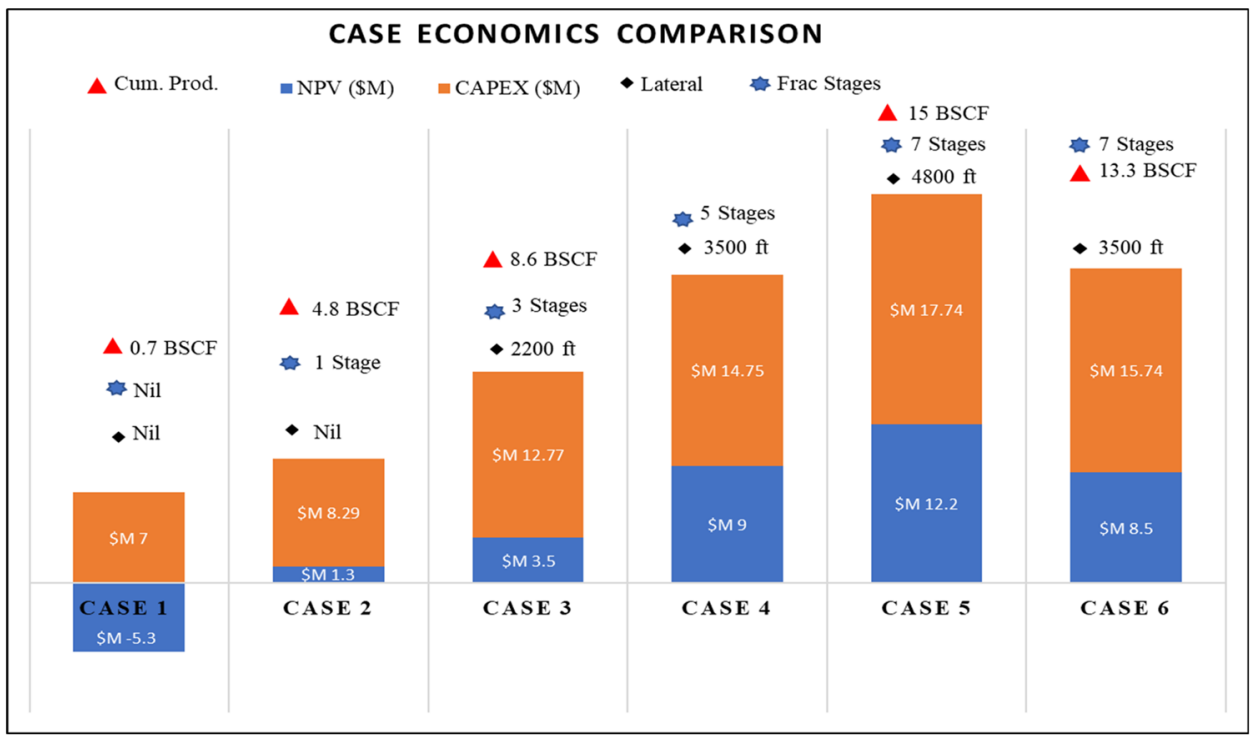

challenge of predicting the impact of a designed hydraulic fracturing job on the tight reservoir performance is addressed through a novel technique that integrates a fracture model with a reservoir simulation model. The integrated approach was utilized in developing a tight sand reservoir of Lower Indus Basin in Pakistan. It is shown that the designing parameters can be optimized through the presented integrated approach to obtain the better overall economics of the given tight reservoir. A water-based fluid system (YF100.1HTD) was selected as the fracturing fluid which is composed of a refined guar gelling agent cross-linked by a borate cross-linker. Smaller proppant size, 20/40 mesh, was 
used to obtain higher fracture length. It is shown that developing tight formations of Pakistan is economically feasible with horizontal well drilling and multi-stage fracturing. The economic model indicated that for a horizontal well with a $4800 \mathrm{ft}$ lateral section, seven-stage fracture treatment was the most profitable case with a net NPV of $\$ 12.2$ million, among all the simulated cases. The presented approach can be utilized to design future hydraulic fracturing treatment for tight gas reservoirs of Pakistan.

Funding This research received no specific grant from any funding agency in the public, commercial, or not-for-profit sectors.

Open Access This article is licensed under a Creative Commons Attribution 4.0 International License, which permits use, sharing, adaptation, distribution and reproduction in any medium or format, as long as you give appropriate credit to the original author(s) and the source, provide a link to the Creative Commons licence, and indicate if changes were made. The images or other third party material in this article are included in the article's Creative Commons licence, unless indicated otherwise in a credit line to the material. If material is not included in the article's Creative Commons licence and your intended use is not permitted by statutory regulation or exceeds the permitted use, you will need to obtain permission directly from the copyright holder. To view a copy of this licence, visit http://creativecommons.org/licenses/by/4.0/.

\section{Bibliography}

Ai K et al (2018) Hydraulic fracturing treatment optimization for low permeability reservoirs based on unified fracture design. Energ $11: 1720$

Alam, S. (2011) Potential of Tight Gas in Pakistan: Productive, Economic and Policy Aspects. Search and Discovery. 80149.

Cohen, C.-E., et al. (2012) Production Forecast after Hydraulic Fracturing in Naturally Fractured Reservoirs: Coupling a Complex Fracturing Simulator and a Semi-Analytical Production Model. Society of Petroleum Engineers-SPE Hydraulic Fracturing Technology Conference 2012.
Dahraj, N.U., et al. Production Strategy of a Tight Gas Carbonate Reservoir in Pakistan. In PAPG/SPE Pakistan Section Annual Technical Conference and Exhibition. 2018.

Guo J, Tao L, Zeng F (2019) Optimization of refracturing timing for horizontal wells in tight oil reservoirs: a case study of Cretaceous Qingshankou Formation, Songliao Basin. NE China Petrol Explor Dev 46(1):153-162

Huang J et al (2018) Well performance simulation and parametric study for different refracturing scenarios in shale reservoir. Geofluids 2018:4763414

Jayakumar, R., et al. (2013) A Systematic Study for Refracturing Modeling Under Different Scenarios in Shale Reservoirs. In SPE Eastern Regional Meeting.

Kolawole, O., et al. (2019) Optimization of Hydraulic Fracturing Design in Unconventional Formations: Impact of Treatment Parameters. in SPE Kuwait Oil \& Gas Show and Conference.

Raza A et al (2019) A review on the natural gas potential of Pakistan for the transition to a low-carbon future. Energ Sour, Part a: Recover, Util Environ Effects 41(9):1149-1159

Salman HM (2015) Hydraulic fracturing design: best practices for a field development plan, in energy engineering and management. Tecnico Lisboa, Portugal

Sharma V, Sircar A, Gupta A (2019) Hydraulic fracturing design and 3D modeling: a case study from Cambay Shale and Eagleford Shale. Multiscale Multidiscip Model, Exp Des 2(1):1-13

Sheikh, S.A.M.S.A. (2012) Reservoir Potential of Lower Nari Sandstones (Early Oligocene) In Southern Indus Basin and Indus Offshore*. Search and Discovery. 50582.

Suboyin A, Rahman MM, Haroun M (2020) Hydraulic fracturing design considerations, water management challenges and insights for Middle Eastern shale gas reservoirs. Energ Rep 6:745-760

Urban, E., et al. (2016) Refracturing Vs. Infill Drilling-A Cost Effective Approach to Enhancing Recovery in Shale Reservoirs. in SPE/ AAPG/SEG Unconventional Resources Technology Conference.

Wang M, Chen S, Lin M (2018) Enhancing recovery and sensitivity studies in an unconventional tight gas condensate reservoir. Pet Sci 15(2):305-318

Waters D, Weijermars R (2021) Predicting the performance of undeveloped multi-fractured marcellus gas wells using an analytical flow-cell model (FCM). Energ 14:1734

Publisher's Note Springer Nature remains neutral with regard to jurisdictional claims in published maps and institutional affiliations. 